\title{
New data on the distribution of Charaea minutum (Joannis, 1865) (Coleoptera: Galerucinae) in Russia: faunistic records from Altai and Sayans
}

\author{
Новые данные по распространению в России \\ Charaea minutum (Joannis, 1865) (Coleoptera: Galerucinae): \\ фаунистические находки из Алтая и Саян
}

\author{
E.V. Guskova ${ }^{1}$, R. Beenen ${ }^{2}$, E.N. Akulov ${ }^{3}$ \\ Е.В. Гуськова ${ }^{1}$, Р. Беенен ${ }^{2}$, Е.Н. Акулов ${ }^{3}$
}

\footnotetext{
${ }^{1}$ Altai State University, Lenina prosp. 61, Barnaul, 656049, Russia.

1 Алтайский государственный университет, пр. Ленина 61, Барнаул 656049, Россия. E-mail: guskovael@mail.ru

2 Martinus Nijhoffhove 51, NL - 3437 ZP Nieuwegein, The Netherlands. E-mail: r.beenen@wxs.nl

${ }^{3}$ All-Russian Center of Plant Quarantine, Krasnoyarsk branch, Maerchaka Str. 31a, Krasnoyarsk, 660075, Russia

${ }^{3}$ Всероссийский центр карантина растений, Красноярский филиал, ул. Маерчака 31a, Красноярск 660075, Россия. Е-таі1: akulich80@yandex.ru
}

KEY WORDS: Altai, Sayans, Charaea, Chrysomelidae, Coleoptera.

КЛЮЧЕВЫЕ СЛОВА: Алтай, Саяны, Charaea, Chrysomelidae, Coleoptera.

ABSTRACT. In Russia Charaea minutum (Joannis, $1865)$ is registered for the first time from Altai and new data on the distribution in the Sayans are given.

РЕЗЮМЕ. Charaea minutum (Joannis, 1865) впервые указывается для Алтая и приводятся новые находки в Саянах.

\section{Introduction}

The status of the genus Charaea Baly, 1878 has been repeatedly revised. The monotypic genus was proposed by Baly [1878] for Charaea flaviventre Baly, 1878. Later on, this genus was not mentioned in literature for a long time. The subsequent new species (later affiliated to Charaea) were mostly treated under the genera Calomicrus Dillwyn, 1829, Exosoma Jacoby, 1903 and Taphinellina Maulik, 1936. Beenen [2010] proposed Taphinellina as a junior synonym of Charaea. Beenen and Warchałowski [2010] listed all species included in this genus. Since then four new species have been described in Charaea [Bezděk, Lee, 2014, Bezděk, 2015] and due to recombination eight species are proposed as additions to this genus [Medvedev, 2011; Bedzěk, 2012]. Taphinellina bengalensis (Jacoby, 1900) was never transferred to Charaea but Bedzěk [2016] recombined it in Cassena Weise, 1892. A detailed taxonomic history of the genus Charaea is presented in Bezděk and Lee [2014].

Now, Charaea includes 44 species [Bezděk, 2015] widespread in eastern Eurasia: China, Japan, Taiwan, Himalayas and India, Russia (East Siberia, Far East), Mongolia, Vietnam, Laos, Thailand, continental Malaysia and Philippines. At least 20 more species are to be described [Bedzěk, 2015]. The genus Charaea is characterized by an elongate oval body, open procoxal cavities, narrow prosternal process, tibiae with apical spine and pygidium without median furrow [Bezděk, Lee, 2014]. Charaea species are very similar externally: metallic blue, bluish black, blackish green or black violet color of pronotum and elytra. They differ in the morphology of the aedeagus and in the color of abdomen, legs and antennae.

In 2014 we registered Charaea minutum (Joannis, 1865 ) in Altai. This discovery has significantly extended the area of the species to the West.

\section{Material}

In order to compile an overview of the distribution of Charaea minutum we studied specimens from various collections. Because of the difficulty in identifying Charaea only specimens we studied ourselves have been included. The examined material is deposited in the following collections: ABCZ - Andrzei Bienkowski Collection, Zelenograd, Russia; EACK — Evgenij Akulov Collection, Krasnoyarsk, Russia; EGCB - Elena Guskova Collection, Barnaul, Russia; FFCJ — Frank Fritzlar Collection Jena, Germany; HHCR - Hans Hebauer Collection, Rain, Germany; ILCM - Igor Lopatin Collection, Minsk, Belarus; MDCA - Manfred Döberl Collection, Abensberg, Germany; MLCL - Michael Langer Collection, Lichtenwalde, Germany; MNHNP - Museum National d'Histoire Naturelle, Paris; RBCN — Ron Beenen Collection Nieuwegein, Netherlands; SMNS - Staatliches Museum für Naturkunde, Stuttgart, Germany; UACB - Ulf Arnold Collection, Berlin, Germany. 


\section{Results}

\section{Charaea minutum (Joannis, 1865)} Figs 1-2.

Luperus minutus Joannis, 1865: 136 (original description). Exosoma minuta: Gressit, Kimoto, 1963: 566 (key).

Luperus (Calomicrus) minutus: Ogloblin, 1936: 27; Lopatin, 1967: 164; 1968: 215; 1971: 229; 1975: 222; Medvedev, Dubeshko, 1974: 133; 1992: 137; Medvedev, Voronova, 1976: 230; 1977a: 340; 1977b: 219; 1979: 121; Medvedev, 1982: 264; 2006: 140; Guselnikov, Medvedev 1984: 26; Dubeshko, Medvedev, 1989: 161; Medvedev, Korotyaev, 1975: 184; Lopatin et al., 2004: 139; Medvedev, Skomorohov, 2009: 43.

Taphinellina minuta: Wilcox, 1973: 450 (new combination); Beenen, 1992: 141-143; Mikhailov, Chashchina, 2009: 179; Beenen, 2010: 489

Charaea minutum: Beenen, Warchałowski, 2010: 210; Lim et al., 2013: 101; Yang et al., 2015: 244.

MATERIAL. New records for Altai and Sayans:

RUSSIA: Altai Rep., Ulagan distr., Chulyshman river Valley, $12 \mathrm{~km}$ SSE Ko village, N 5058'; E 8756', 6-8.07.2013, h-550 m, leg. R.Yakovlev (EGCB: $1 \sigma^{7}, 4$ क्ष); Krasnoyarsk, Akademgorodok, 9.07.2014, leg. E.Akulov (EACK: 1 ○', 3 우); Krasnoyarsk, Udachnyj vill., 2.07.2014, leg. E.Akulov (EACK: 1 ऽ', 3 우).

Additional material examined.

Type: The male type specimen from "Daouri" in MNHNP is labelled as follows: "Luperus minutus Mannerh. Dauria", "Museum Paris ex. coll. R. Oberthur Reiche",'TYPE".

We should note that the type habitat of the species is very inaccurate. «Dauria» refers to the vast plain area mainly of eastern Transbaikal near the borders of Russia, north-eastern Mongolia and China. «Selenginskaya Dauria» refers to the steppe of the Selenga river valley in Buryatia and northern Mongolia. Thus, the region called «Dauria» involves at least three large regions: the Republic of Buryatia, Transbaikal and north-eastern Mongolia.

Other material: RUSSIA: Minusinsk, 17.06.2011, leg. E.Akulov (EACK); Irkutsk reg., SW-Baikal, Bolshoe Goloustnoye, 16-19.07.2012, leg. S.Flossmann (FFCJ); same label, 11-25.06.2011, leg. S.Flossmann (FFCJ); Siberia orient., Baical Sea, 20.06.1912, leg. Kuligin (ILCM); 5 ex. Irkutsk, leg. "W. Jacovlev" (ILCM); 1 ex., Buryatia, Selenginskyj District, $3 \mathrm{~km}$ from the confluence of the rivers Abiduj and DundaSaga, 18.07.2008, leg. P.Petrov (ABCZ); 3 ex., Amur reg., Blagoveshchensk, 29.06.1997, (HHCR); 2 ex. Amur reg., Amur River, Blagoveshchensk, 29.06.1997, leg. Dr.Louda (MLCL); 6 ex., Primorskij Kraj, Novochuguevka, 20.07.1990, leg. Boukal (UACB); 1 ex., Primorskij Kraj, 5 km E Kraskino,13-16.07.1992, leg. Boukal (UACB); Primorskij Kraj, Lake Khanka, 5.08.1918, (ILCM); 3 ex., Primorskij Kraj, Ussuri Region, Novovarvarovka, 6-10.07.1989, leg S. Becvar (UACB); 2 ex., Suchan [Partizansk] near Vladivostok, leg. Kurnakov (ILCM). MONGOLIA: Chentej aimak, Candagan Tal, $40 \mathrm{~km}$ Ö. v. Somon Zargaltchaan, 1300m, 28.07.1965, Exp. Dr. Kaszab (ILCM); Chentej aimak, $5 \mathrm{~km}$ west of Mörön, $1200 \mathrm{~m}$, 25-26.06.1976, leg L. N. Medvedev \& N.Woronowa (SMNS); Chentej ajmak, Mörön-gol, 07.1985, leg. B. Malec (MDCA, RBCN); 32 ex., Central aimak, Ulan Bator env., 07.1985, leg. B. Malec (MDCA, RBCN).

DISTRIBUTION. Based on specimens we studied ourselves, the distribution of C. minutum includes Russia: Western Siberia (Altai, new record), Eastern Siberia (Krasnoyarsk kraj: Krasnoyarsk, new record), Khakassia (W Sayany), Tuva, Irkutsk region, Dauria), Far East (Amur region, Yevreyskaya avtonomnaya oblast, Primorskij Kraj) and Mongolia (Chentej and Central Aimaks). C. minutum is also recorded from Korea and China (Heilongjiang, Jilin, Sichuan) [Beenen, 2010; Yang et al., 2015].

BIONOMICS. The biology of $C$. minutum is not studied. In Primorye, feeding of beetles on Clematis (Ranunculaceae) was indicated [Dubeshko, Medvedev, 1989]. Medvedev and Roginskaja [1988] list Pulsatilla (Ranunculaceae), and questionably Artemisia (Asteraceae) and Erysimum (Brassicaceae). It is likely that $C$. minutum feeds on Ranunculaceaea.

DIAGNOSIS. In Russia, two species have been recorded: Charaea minutum (Joannis, 1865) and C. flaviventris (Motschulsky, 1960). In 2010, Beenen and Warchałowski described a new species $C$. pseudominutum Beenen et Warchalowski, 2010 from China (Hubei) which is very similar to C. minutum. Here we give a key for a reliable determination of these three species.

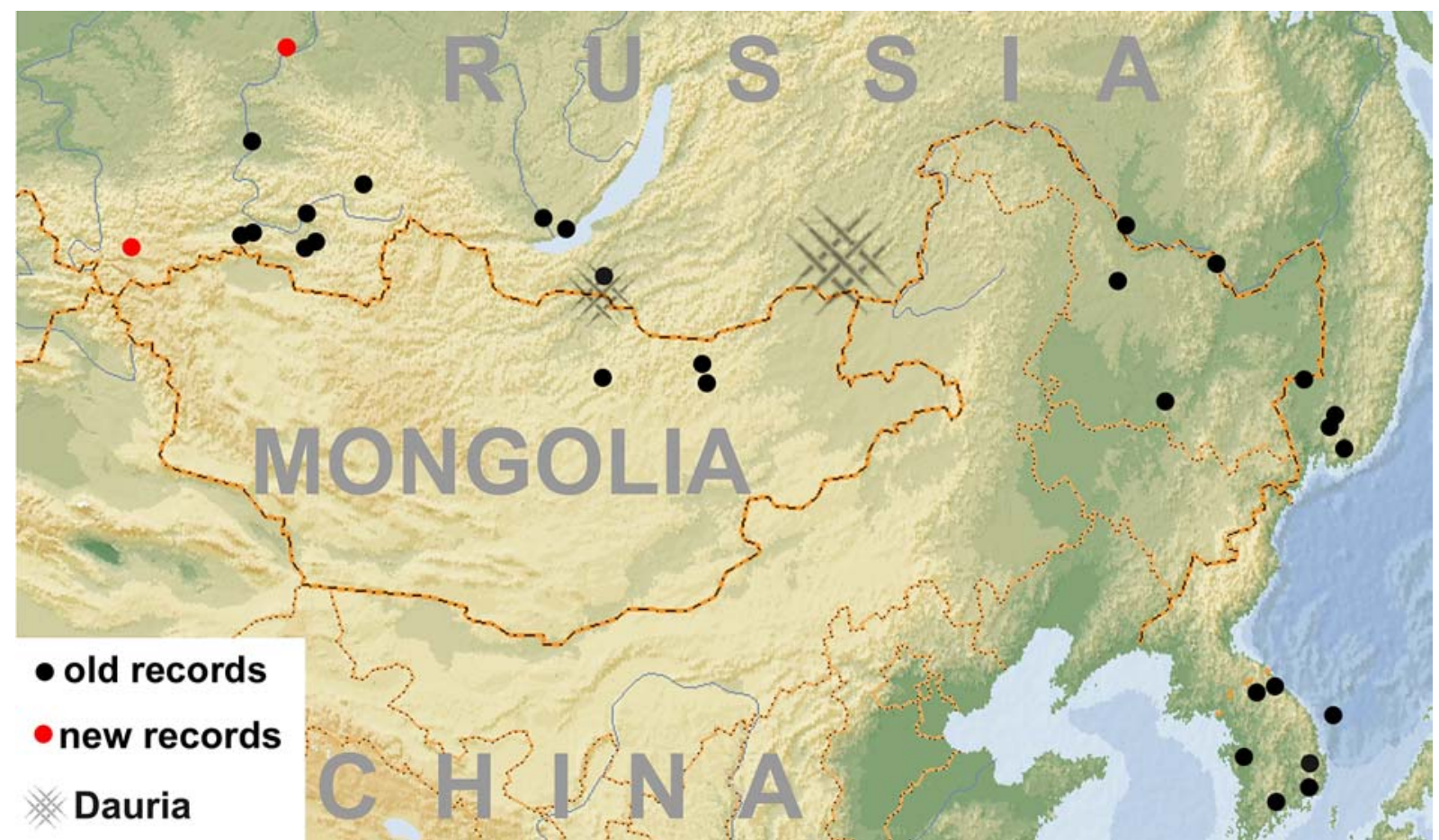

Fig. 1. Distribution map of Charaea minutum.

Рис. 1. Карта распространения Charaea minutum. 


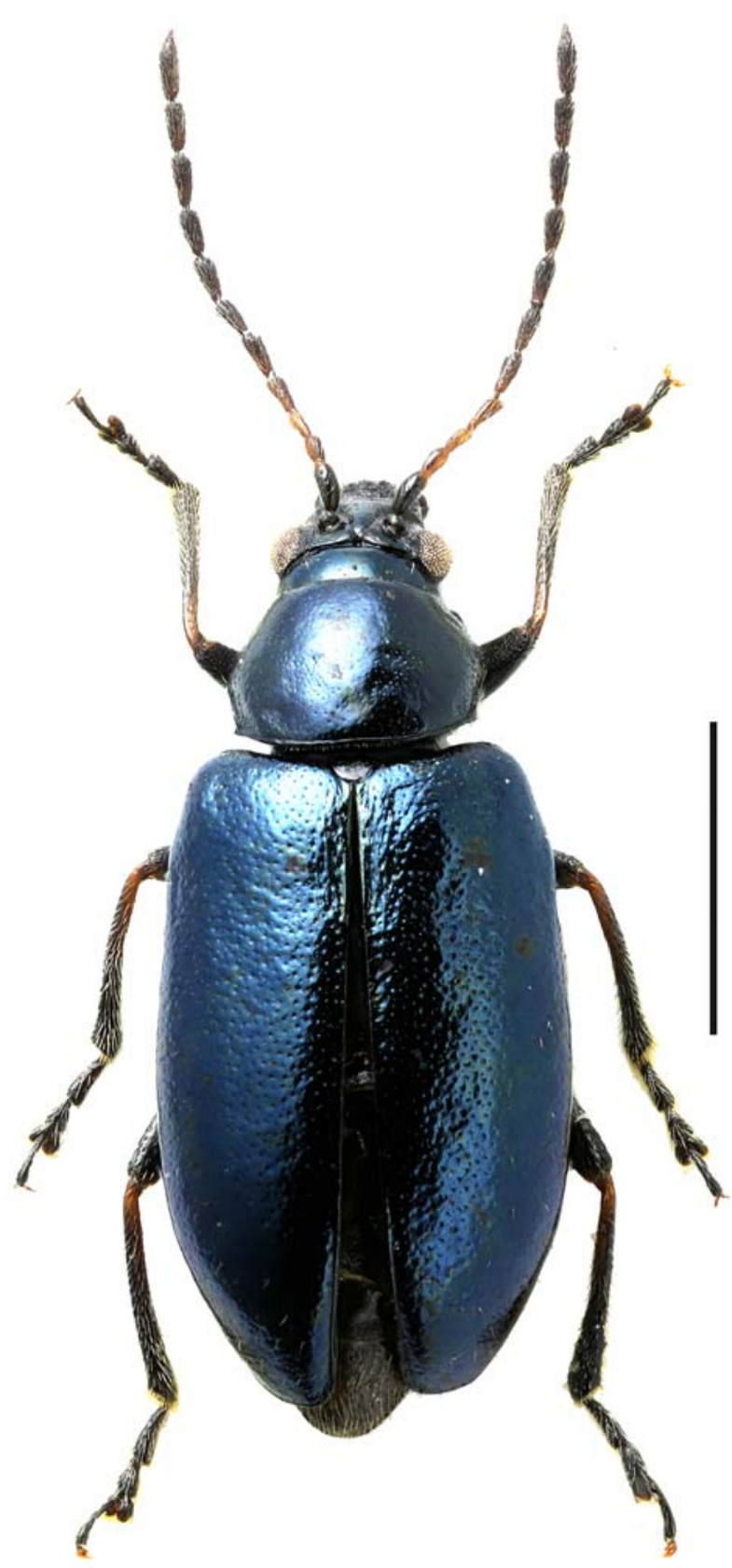

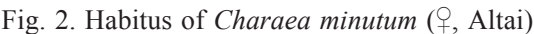
Рис. 2. Габитус Charaea minutum (†, Алтай)

\section{Key to CharaEa of Russia AND SIMILAR SPECIES}

1. Abdomen completely or almost completely dark brown to black 2

- Abdomen completely yellow. Upper side bluish black, sometimes pronotum black violet or elytra black green. Antennae and legs dark brown to black with lighter base tibiae. Body length 4.3-6.0 mm.

C. flaviventre (Motschulsky) (distributed in Russian Far East, Eastern Siberia, China, Korea and Japan; host plants: Alnus (Betulaceae), Salix (Salicaceae).

2. Abdomen completely dark brown or black. Upper side metallic bluish black or green. Legs: femora dark brown with the apex a little lighter; tibiae yellowish at base, darker to the apex. Antennae black with the antennomere

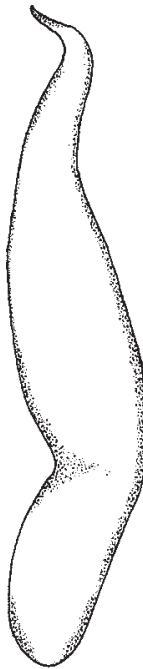

3

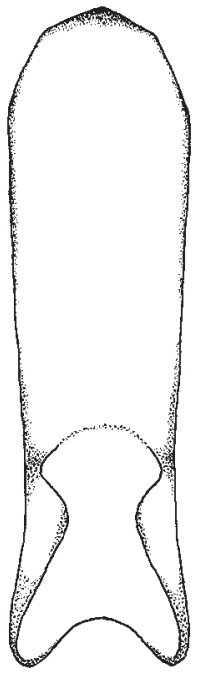

4

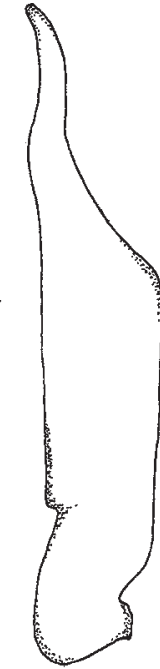

5

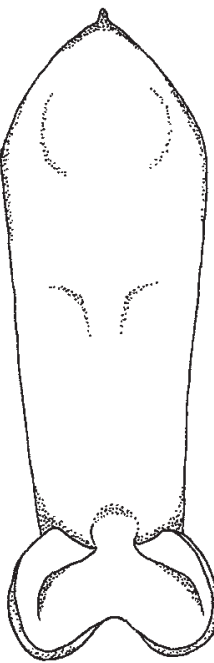

6
Figs 3-6. Charaea ssp., aedeagus: 3-4 - Ch. minutum; 5-6Ch. pseudominutum; 3, 5- lateral side; 4, 6 - ventral side.

Рис. 3-6. Charaea ssp., эдеагус: 3-4-Ch. minutum; 5-6Ch. pseudominutum; 3, 5- сбоку; 4, 6- снизу.

$2-3$ or $2-4$ are yellowish. Aedeagus in lateral view the tip strongly curved twice (S-shaped) and in ventral view is more parallel in basal three quarters (Figs 3-4). Body length 2.7-3.8 $\mathrm{mm}$...................... C. minutum (Joannis) (distributed in Russian Far East (Amur region, Primorskij Kraj, Sakhalin, S Kuril Islands), Japan, Korea, China; host plants: Ranunculaceaea.

- Abdomen completely dark brown to black except the ultimate and part of the penultimate segment which are yellow. Upper side metallic blue. Legs and antennae dark brown to black. Aedeagus in ventral view gradually expanding from base towards the apical quarter. From there abruptly narrowing towards the tip which is pointed. In lateral view tip of the aedeagus is faintly curved twice (Figs 5-6). Body length 3.2-3.4 mm.

C. pseudominutum Beenen et Warchałowski (distributed in China (Hubei), Korea; host plants is not known).

\section{Discussion}

The widespread East-Asian genus Charaea (including also tropical species) is distributed up to Altai in the West. The maximum number of species of the genus Charaea can be found in South-Eastern Asia. It is possible that in the Pliocene, when the climate was warm and humid, the species of the genus were widely distributed in Siberia. By the end of the Pliocene era, and especially, in the Pleistocene, sharp cooling and drying of the climate led to the shift of northern boundaries of the habitats to the south. The species tolerant to low temperatures could survive in this climate and remained in south Siberian refugia. Recent records of $C$. minutum from Altai might indicate a recent invasion. However, it cannot be excluded that this species has been overlooked during historic collecting.

The Altai mountains are a barrier for taxa distribution both in latitudinal and longitudinal direction. Such examples of distribution of insect genera are rare, there are some examples among Coleoptera: Dendrobaris Egorov, 1976 
(Curculionidae), Kuatania Evers, 1948 (Malachiidae), Epaphiopsis Uéno, 1953 (Carabidae) [Dudko, 2011; Legalov, Borisova, 2011; Tshernyshev, 2012] and Lepidoptera: Ahlbergia Bryk, 1946 (Lycaenidae) and Caligula Moore, 1862 (Saturniidae) [Tuzov, 2000; Huang, Zhu, 2016; Izerskij, 1999]. A similar distribution occurs in the field mouse Apodemus peninsulae (Muridae) and is associated with a refugium in the Russian Far East during the Quaternary glaciations and subsequent dispersal directed by the complex topography of the area wherein biogeographic barriers (Gobi desert, Yunnan Guizhou Plateau, Dzungaria basin, and others) play a prominent role [Sakka et al., 2010]. At present, it is impossible to make conclusions about similarities, because of the limited detailed information on Charaea and other insect species. However the Altai mountains, defined as one of the barriers by Sakka et al. [2010], seems to have been crossed by C. minutum.

ACKNOWLEDGEMENT. The authors express their gratitude to A.A. Gusakov and K.V. Makarov (Moscow, Russia) for making photograph. We are also grateful to R.V. Yakovlev (Barnaul, Russia) for his assistance in the map plotting.

\section{References}

Baly J.S. 1878. Descriptions of the phytophagous Coleoptera collected by the late Dr. F. Stoliczka during Forsyth's expedition to Kashgar in 1873-74 // Cistula Entomologica. Vol.2 (1875-1882). P.369-383.

Beenen R. 1992. The identity of Luperus minutus Joannis, 1865 (Coleoptera: Chrysomelidae) // Entomologische Berichten, Amsterdam. Vol.52. No.10. P.141-143.

Beenen R. 2010. Galerucinae // Löbl I., SmetanaA. (eds.). Catalogue of Palaearctic Coleoptera, 6. Stenstrup, Apollo Books. P.443-491

Beenen R., Warchałowski A. 2010. Charaea pseudominutum n.sp., an undescribed but not unknown galerucine beetle (Coleoptera, Chrysomelidae, Galerucinae) // Entomologische Blätter. Vol.106. P.57-62.

Bedzěk J. 2012. Taxonomic and faunistic notes on Oriental and Palaearctic Galerucinae and Cryptocephalinae (Coleoptera: Chrysomelidae) // Genus. Vol.23. P.375-418.

Bedzěk J. 2015. Charaea luzonicum sp. nov. (Coleoptera: Chrysomelidae: Galerucinae): the first record of Charaea in the Philippines // Revue suisse de Zoologie. T.122. P.371-375.

Bedzěk J. 2016. Redescription and identity of Taphinellina bengalensis Jacoby, 1900 (Coleoptera: Chrysomelidae: Galerucinae) // Turkish Journal of Zoology. Vol.40. P.120-124.

Bedzěk J., Lee Ch.-F. 2014. Revision of Charaea (Coleoptera: Chrysomelidae: Galerucinae) from Taiwan // Zootaxa. Vol.3861. P.1-39.

Dubeshko L.N., Medvedev L.N. 1974. [Leaf beetles of Middle Siberia] // Insect fauna of East Siberia and Far East. Irkutsk. P.105146 [in Russian].

Dubeshko L., Medvedev L.N. 1989. [Ecology of Chrysomelidae from Siberia and Far East]. Irkutsk: Irkutsk University. 224 p. [in Russian].

Dudko R.Yu. 2011. [Relict beetles (Coleoptera: Carabidae, Agyrtidae) with Altai - East Asian disjunctive range] // Euroasian Entomological Journal. Vol.10. No.3. P.349-360 [in Russian].

Guselnikov S.A., Medvedev L.N. 1984. [Chrysomelidae of West Sayan Mts and Minusinsk depression] // Coleoptera of Siberia. Irkutsk. P.15-32 [in Russian].

Gressit J.L., Kimoto S. 1963. The Chrysomelidae of China and Korea. Part 2 // Pacific Insects Monograph. Vol.1B. P.301-1026.

Huang H., Zhu J.-Q. 2016. Ahlbergia maoweiweii sp. n. from Shaanxi, China with revisional notes on similar species (Lepidoptera: Lycaenidae) // Zootaxa. Vol.4114. No.4. P.409-433.

Izerskij V.V. 1999. Bombicoidea and Notodontidae of Siberia and Far East. Kiev: Gnozis. 160 p. [in Russian].

Joannis M., de. 1865. Monographie des galerucides d'Europe, du Nord de l'Afrique et de l'Asie. Tribu des galerucides proprement dites ou isopodes. L'Abeille. Vol.3[1866]. P.1-168.
Lim J.-S., Park S.-Y., Lim J.-O., Lee B.-W. 2013. A Faunistic Study of Insects from Is. Ulleungdo and Its Nearby Islands in South Korea // Journal of Asia-Pacific Biodiversity. Vol.6. No.1. P.93-121.

Legalov A.A., Borisova H.V. 2011. [First record of Dendrobaris tatjanae (Egorov, 1976) (Coleoptera, Curculionidae) from Krasnoyarskii Krai] //Euroasian Entomological Journal. Vol.10. No.1. P.72-73 [in Russian].

Lopatin I.K. 1967. Chrysomelidae der III. Expedition. Ergebnisse der zoologischen Forschungen von Dr. Z. Kaszab in der Mongolei (Coleoptera) // Reichenbachia. Vol.9. No.18. P.157-169.

Lopatin I.K. 1968. Chrysomelidae der IV. Expedition. Ergebnisse der zoologischen Forschungen von Dr. Z. Kaszab in der Mongolei (Coleoptera) // Reichenbachia. Vol.11. No.19. P.207-220.

Lopatin I.K. 1971. Chrysomelidae VI. Ergebnisse der zoologischen Forschungen von Dr. Z. Kaszab in der Mongolei (Coleoptera) // Faunistische Abhandlungen des Staatlichen Museums für Tierkunde. Dresden. Vol.3. No.18. P.219-233.

Lopatin I.K. 1975. [The Leaf-beetles Coleoptera, Chrysomelidae of the Mongolian People's Republic] // Insects of Mongolia. Vol.3. P.191-233 [In Russian].

Lopatin I.K., Aleksandrovich O.R., Konstantinov A.S. 2004. Check list leaf-beetle Chrysomelidae (Coleoptera) of the Eastern Europe and Northen Asia. Olsztyn. 343 p.

Medvedev L.N. 1982. [Chrysomelidae of MPR: Key]. Moscow. Nauka. 340 p. [in Russian].

Medvedev L.N. 2006. [Contribution to the fauna of leaf-beetles (Coleoptera, Chrysomelidae) of Amur Oblast] // Euroasian Entomological Journal. Vol.5. No.2. P.137-143 [in Russian].

Medvedev L.N. 2011. A contribution to knowledge of Oriental species of Cneorane Baly, 1865 (Chrysomelidae, Galerucinae) // Entomologica Basiliensia et Collectionis Frey. Vol.33. P.351-368.

Medvedev L.N., Dubeshko L.N. 1992. [A key to Chrysomelidae of Siberia]. Irkutsk University edition. 220 p. [in Russian].

Medvedev L.N., Korotyaev B.A. 1975. [Leaf beetles fauna of Tuva and North-West Mongolia (Coleoptera, Chrysomelidae), 1] // Insects of Mongolia. Vol.3. P.177-191 [in Russian].

Medvedev L.N., Roginskaja E.J. 1988. [Catalogue of the foodplants of the leaf beetles of the U.S.S.R.] Moscow. 191 p. [in Russian].

Medvedev L.N., Skomorohov M.O. 2009. [To the fauna Leaf beetles (Coleoptera, Chrysomelidae) of Yevreyskaya avtonomnaya oblast] // Regionalnye problemy. Vol.12. P.41-45 [in Russian].

Medvedev L.N., Voronova N.V. 1976. [On the fauna leaf beetles (Coleoptera, Chrysomelidae) of Mongolia, 1] // Insects of Mongolia. Vol.4. P.222-236 [in Russian].

Medvedev L.N., Voronova N.V. 1977a. [On the fauna of leaf-beetles (Coleoptera, Chrysomelidae) of Mongolia, 2] // Insects of Mongolia. Vol.5. P.319-372 [in Russian].

Medvedev L.N., Voronova N.V. 1977b. The statial distribution of Leaf beetles of dry steppe zone of Central Mongolia // Flora and Fauna MPR (Mongolia). P.215-222 [in Russian].

Medvedev L.N., Voronova N.V. 1979. On the fauna of leaf-beetles (Coleoptera, Chrysomelidae) of Mongolia, 3 // Insects of Mongolia. Vol.6. P.97-135 [in Russian].

Mikhailov Yu. E., Chashchina O.E. 2009. Family Chrysomelidae // In: Storozhenko S. Yu. (Ed.). Insects of Lazovsky Nature Reserve. Dalnauka. Vladivostok. P.171-181 [in Russian].

Ogloblin D.A. 1936. Chrysomelidae, Galerucinae. Fauna SSSR, Nasekomye zhestkokrylye Vol.26. No.1. Academy of Sciences of the USSR. Moscow - Leningrad. P.1-455 [in Russian].

Sakka H., Quéré J. P, Kartavtseva I., Pavlenko M., Chelomina G., Atopkin D., Bogdanov A., Michaux J. 2010. Comparative phylogeography of four Apodemus species (Mammalia: Rodentia) in the Asian Far East: evidence of Quaternary climatic changes in their genetic structure // Biological Journal of the Linnean Society. Vol.100. P.797-821.

Tshernyshev S.E. 2012. [A review of soft-winged flower beetle fauna (Coleoptera, Malachiidae) of North Asia] // Euroasian Entomological Journal. Vol.11. No.6. P.575-587 [in Russian].

Tuzov V.K. 2000. Genus Ahlbergia. In: Guide to the butterflies of Russia and adjacent territories (Lepidoptera, Rhopalocera). Sofia-Moscow: Pensoft. Vol.2. P.118-120.

Wilcox J.A. 1973. Chrysomelidae, Galerucinae, Luperini: Luperina. Coleopterorum Catalogus. Supplementa. Vol.78. P.433-664.

Yang X., Ge S., Nie R., Ruan Y., Li W. 2015. Chinese Leaf Beetles. Science Press. Beijing. P.1-507. 